wards projected. It is found that an apparently continuous flow of the image on the screen can be obtained if about seven frames are exposed for each section. The camera is mounted between the microscope and a paper screen, sharp focus of the former being secured by exposing a number of frames at recorded settings of the fine adjustment; the camera is then swung out of the optical axis and the image brought to a sharp focus on the screen by means of a supplementary lens. The screen is now used to secure orientation and focus for each successive section, the camera being swung into the optical axis when a suitable adjustment has been obtained. Though much difficulty is at present occasioned through the distortion of successive sections during mounting, the new technique will prove a considerable aid both in teaching and in research.

\section{Development of International Law}

The New Commonwealth (monthly, published at Mowbray House, Norfolk Street, Strand, W.C.2., price $6 d$. ), the first issue of which has recently appeared, is the organ of a new international socicty formed to advocate the establishment of a world system of law and order. If "the common sense of all" is to "hold a fretful realm in awe", effective provision must be made for the administration of international justice, and this can be achieved only, in the new society's view, by establishing : (1) an international tribunal, to deal with all disputes threatening the peace of the world which do not at present come within the purview of the Permanent Court of International Justice ; and (2) an international police force as the sanction of international law and a guarantee of security against aggression. On these two objectives the society proposes to focus and interest public opinion. As Sir Arthur Salter says in a letter to the editor, the times are dangerous and moral suasion alone cannot be relied upon to defeat the material forces of the world if these are all allowed to be harnessed to policies of evil. In an open letter signed by Norman Angell, Lord Cecil of Chelwood, the Archbishop of York, Sir Oliver Lodge, Prof. Gilbert Murray and sixteen other eminent citizens of nine of the principal countries of the world, the New Commonwealth is commended to all those who are interested in the development of the reign of law.

\section{Production and Employment}

IN a pamphlet entitled "The Prevention of Future Economic World Crises", Herr Robert Bosch of the Bosch Company, Stuttgart, points out that the present world-wide business depression differs radically from previous ones which were caused principally, if not exclusively, by a preceding unhealthy boom. $\mathrm{He}$ argues that the troubles of the present depression are not due to over-efficiency of production methods as commonly supposed but rather to the inefficiency and backwardness of nontechnical branches of the world's activities. Foreign relations are handicapped by antiquated political and mercantilist conceptions leading to armaments and tariffs while national prosperity is handicapped by wasteful and inefficient administration and distribution and by antagonism between different groups of society. It is necessary to write off superfluous plant capacity so that the remaining factories may be run efficiently. Herr Bosch visualises a reduction of the yearly working time to 1800 hours or less in place of the present 2400 hours so as to guarantee some employment at fair compensation to every worker, but he recommends that the rigid eighthour day should be replaced by more flexible arrangements so as to provide the maximum economy in the operation of particular factories.

\section{Scientific Treatment of Delinquency}

A NEW era in the investigation and treatment of crime was outlined at an inaugural meeting of the 'Institute for Scientific Treatment of Delinquency' held at University College, London, on November 29. The chairman, Dr. Edward Glover, pointed out that existing criminal and penal codes differ in no essential respect from the behaviouristic codes spontaneously evolved by two-year old children. He emphasised the urgent need for centralisation and co-ordination of effort at present made by small independent organisations. In his opinion any research on the subject should be conducted in an attitude of complete detachment from preconceived views as to desirability. The need for such an Institute was emphasised by a number of speakers. Amongst these, Lord Feversham dealt with the problem from the point of view of adequate probationary handling. Drs. Hadfield, Rees and Emanuel Miller recounted medico-psychological experience of handling delinquents at various clinics and welfare centres. The points of view of general science, ethics and politics were presented by Prof. Winifred Cullis, Canon Donaldson and W. J. Brown respectively. The Institute's immediate plans for co-ordination research, treatment and technical instruction were then outlined by Dr. Glover. It is hoped that within a short time a reasoned report on the present system of criminological work may be put before the various Government departments concerned. All communications should be addressed to the honorary secretary of the Institute, 56 Grosvenor Street, London, W.1.

\section{The Study of an Oilfield}

Some observations on this subject were made by Mr. J. W. Weil in a paper read before the Institution of Petroleum Technologists on October 11. The paper was perhaps timely as representing the case for petroleum geology taking its logical place in the systematic scheme of oil production. Latterly there has been a decided tendency to interpret underground reservoir conditions-even geological dataon the basis of such functions as flowing pressures, oil and gas measurements, gas-oil ratios and other physical determinations which have been advanced as part of the standard technique of production engineering. The author pleads, and rightly so, for a thorough geological investigation as precedent to oilfield development and, in this connexion, he stresses the necessity of adequate study of stratigraphy, structure, factors influencing the accumula.

No. 3292, VoL. 130] 
tion of oil and gas, data necessary for correlation of horizons and the construction of stratigraphical and production maps. While there is clearly nothing strikingly new in this communication, the paper will have done good if it directs the attention of those primarily concerned to the fact that, while geology may be substantially aided by the applications of its contact sciences, its principles as governing the understanding of sub-surface oil pools can never be super. seded.

\section{Mining Research at Birmingham}

THE Executive Board of Mining Research of the University of Birmingham has issued a report on the work of the Mining Research Laboratory for the year 1931. The Laboratory receives grants from the British Colliery Owners' Research Association, the Department of Scientific and Industrial Research, and the Miners' Welfare Fund, which supports work in connexion with the problems of safety in mines. The report bears witness to the wide range of sciencesphysics, chemistry, geology, and physiology-which are focused upon the problems of the coal industry. Much attention continues to be given to spontaneous combustion, as underground heatings are a prolific source of danger and accident. For some years the Laboratory has examined the hydrogenation of coal. While this problem has come to be regarded as technically solved, economic success seems to be so remote that the work has been suspended. Attention is being turned to problems connected with the use of compressed gas for road transport.

\section{Social Conditions of Miners in India}

THE September part of the most recent volume of the Transactions of the Mining and Geological Institute of India contains an important paper by Mr. R. R. Simpson, chief inspector of mines in India, upon the social conditions of miners in India, together with an animated discussion upon it. The paper is particularly interesting in itself, and all the more so because it discusses in detail a number of the very numerous recommendations made by the Royal Commission sent out in 1929 to inquire into Indian labour conditions, which made its report in 1931. The members who discussed the paper expressed varying views, and evidently looked upon $\mathrm{Mr}$. Simpson's paper as a peg on which to hang the discussion of the recommendations of the Royal Commission. The paper and discussion occupy considerably more than fifty pages, and, therefore, do not lend themselves to any ready abstract, but both are well worth careful study on the part of those who wish to understand thoroughly Indian labour conditions.

\section{Exhibition of Chemical Plant at Cologne}

"Achema VII", the seventh exhibition of chemical plant and equipment organised by the Deutsche Gesellschaft für chemisches Apparatewesen ("Dechema"), is to be held at Cologne on June 2-11, 1933. Similar exhibitions have been held since 1920 in Hanover, Stuttgart, Hamburg, Nürnberg, Essen, and Frankfurt-am-Main. The exhibition next year will be associated with meetings of the Verein deutscher Chemiker and other technological associations, in particular the Deutsche Brennkrafttechnische Gesellschaft and the Deutsche Kautschukgesellschaft, and with a Rubber Exhibition which will form the summer exhibition of the city of Cologne and will remain open until October 1933. The three principal halls around the congress hall in the Rheinpark will contain examples of acidproof stoneware and other ceramic products, technical instruments for measurement and control, nonmetallic and non-ferrous plant, laboratory apparatus and instruments, and machinery, with examples of complete plant and processes, raw materials and products. The rubber section will illustrate historically the development of methods for the production of rubber and of its industrial applications. An exhibition of such character will necessarily attract international interest, and nowhere more than in countries where chemical industries and the manu. facture of chemical plant have reached a high standard of attainment. Particulars of the exhibition can be obtained from "Dechema", Seelze, near Hanover.

\section{Mosquito Control}

UNDER the title of "A Mosquito Summary", Mr. John F. Marshall, director of the British Mosquito Control Institute, Hayling Island, Hants., has recently issued an illustrated pamphlet of an essentially practical character. In a short and concise manner it explains how to recognise a mosquito, how such insects breed and how to distinguish anophelines from culicines in all stages of life. The manner in which mosquitoes carry disease and methods of controlling these insects are also summarised. The pamphlet, which is obtainable from the Institute (price 9d.) should prove useful to health officers and others concerned with mosquito eradication.

\section{Dairy Research}

WE have received the annual report for the year ended July 31, 1931, of the National Institute for Research in Dairying at the University of Reading. In common with other Institutions, a restricted income has necessitated a percentage reduction upon all salaries and wages and a curtailment of research work, the Government's grants for 1931-32 being less than previously by nearly $£ 2,000$. An account is given of the work of the various departments, with brief abstracts of scientific contributions made by the staff. An obituary notice, with portrait, of the late director, Dr. Stenhouse Williams, is included.

\section{Bishop's Ring and the Andean Eruption}

Mr. J. Fraser Paterson, writing from Broken Hill, Australia, says :-- "The rare phenomenon known as Bishop's ring was visible in the western sky at 5 P.M. on Saturday, July 23. This date is about ten and a half weeks after the Andean eruptions. The colour of the ring was sepia."

No. 3292, Vol. 130] 